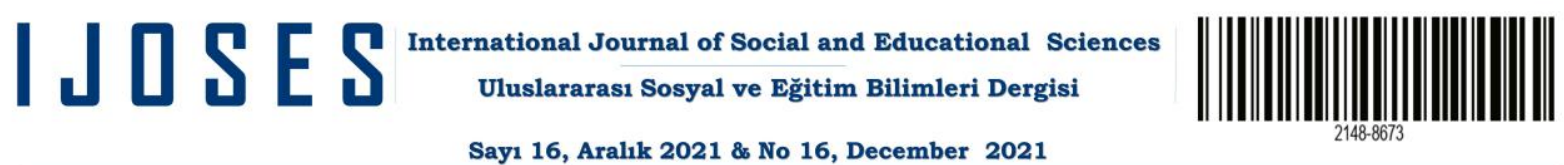

\section{Kavramsal Bilginin Gelişiminin İncelenmesi: Cebirsel Kesirli İfadeleri İçeren Denklemler Bağlamında}

Examining the Development of Conceptual Knowledge: In the Context of Equations Containing Algebraic Fractional Expressions

\author{
Mehtap Taştepe \\ Dr. Öğretim Üyesi \\ Sinop Üniversitesi \\ mehtap.tastepe@hotmail.com
}

ORCID ID: 0000-0002-4535-3606

\author{
Hüseyin Bahadır Yanık \\ Prof. Dr. \\ Anadolu Üniversitesi \\ hbyanik@yahoo.com
}

ORCID ID: 0000-0001-7769-2306

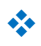

\section{Makale Bilgisi / Article Information} \\ Makale Türü / Article Type : Araştırma Makalesi \\ Geliş Tarihi / Received : 8 Temmuz 2021 \\ Kabul Tarihi / Accepted : 17 Ekim 2021 \\ Yayın Tarihi / Published : 15 Aralık 2021 \\ DOI Number : :10.20860/ijoses.967628

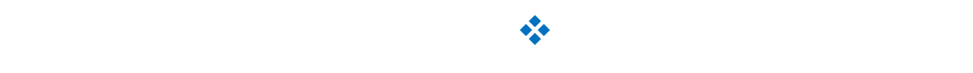

"Bu çalışma Anadolu Üniversitesi BAP birimince desteklenmiştir.

Proje No: 163E099"

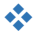

\section{Kaynak Gösterme / Citation}

Taştepe, M. \& Yanık, H. B. “Kavramsal Bilginin Gelişiminin İncelenmesi: Cebirsel Kesirli İfadeleri İçeren Denklemler Bağlamında". Uluslararası Sosyal ve Eğitim Bilimleri Dergisi, 16 (2021): 83-103. 


\title{
Kavramsal Bilginin Gelişiminin İncelenmesi: Cebirsel Kesirli İfadeleri İçeren Denklemler Bağlamında
}

\author{
Examining the Development of Conceptual Knowledge: In the Context of Equations Containing Algebraic \\ Fractional Expressions
}

\section{Mehtap Taştepe \& Hüseyin Bahadır Yanık}

$\ddot{O} z$

$\mathrm{Bu}$ araştırmanın amacı, cebirsel kesirli ifadeleri içeren denklemlerde katılımcıların kavramsal bilgilerindeki değişimi incelemektir. Bu araştırmada yürütülen öğretim sürecinde katılımcılardan cebirsel kesirli ifadeleri içeren denklemlere sözel problem yazmaları istenerek, kavramsal anlamaya dair bilişsel yapılarının değişimleri izlenmiştir. Bu Araştırmanın modelini "öğretim deneyi", bunu desteklemek için yapılan "klinik görüşmeler" ve "doküman incelemesi" oluşturmaktadır. Araştırmadan elde edilen veriler içerik analizi yöntemiyle analiz edilmiştir. Araştırma 2015-2016 öğretim yılında Türkiye'de bir ilde iki farklı lisede öğrenim gören 4 dokuzuncu sınıf öğrencisi ile gerçekleştirilmiştir. Elde edilen verilere göre, katılımcılar diğer çalışmalara benzer şekilde önce kesrin anlamını oluşturmuş, ardından sözel problem yazabilmişlerdir. Bu araştırmada yazılan sözel problemlerde en çok kullanılan anlamlar kesrin bölüm, oran ve ölçme anlamları olurken, işlemci ve parça bütün anlamları ise en az kullanılan anlamlar olmuştur. Literatüre gore, nümerik kesirlerle ilgili en çok kullanılan anlam ise bu araştırmanın aksine parça bütün anlamıdır. Kullanılan kesrin anlamlarının, kesrin türü ile ilişkili olduğu belirlenmiştir. Sözel problem yazarken, katılımcıların hatalar yaptığı ve kesrin farklı anlamlarına göre yapılan hataların da farklıık gösterdiği belirlenmiştir. Alanyazında bu sonuç ile ilgili herhangi bir çalışmaya rastlanmamıştır. Bu araştırmanın uygulama süresi ve yöntemi göz önünde bulundurularak farklı kavramlara dair farklı düzeyde katılımcıların kavramsal değişim süreçleri incelenebilir.

Anahtar Kelimeler: Kavramsal Bilgi, Cebirsel Kesirler, Denklemler, Problem Kurma.

\section{Abstract}

The purpose of this research is to examine the change in the conceptual knowledge of the participants in equations containing algebraic fractional expressions. In a teaching process carried out in this research, by asking the participants to write word problems on equations containing algebraic fractional expressions, the changes in the cognitive structures of conceptual understanding were monitored. The model of the research is "teaching experiment", "clinical interviews" and "document review" to support this. The obtained data were analyzed by content analysis method. The research was carried out with 4 ninth grade students studying in two different high schools in a city in Turkey in the 2015-2016 academic year. According to the data obtained, Similar to other studies, the participants first formed the meaning of the fraction and then they were able to write a word problem.In the verbal problems written in this research, the most used meanings were fraction, ratio and measurement, while operator and part whole meanings were the least used meanings.According to the literature, the most used meaning related to numerical fractions is the part and whole meaning, contrary to this research. It was determined that the participants made mistakes while writing a verbal problem and the mistakes made according to the different meanings of the fraction also differed. No study has been found in the literature regarding this result. Considering the implementation period and method of this research, the conceptual change processes of the participants at different levels regarding different concepts can be examined.

Keywords: Conceptual Knowledge, Algebraic Fractions, Equations, Problem Posing. 


\section{Extended Summary}

\section{Purpose and Significance:}

Mathematics is known as one of the courses with the most intense content since the past. Algebra, one of the subject areas with the highest content; It has an important place in both mathematics and mathematics education. One of the sub-learning areas of this subject area is equations containing algebraic fractional expressions, which include both the subject of equations and the subject of fractions. At the point of learning algebra in a meaningful way, it is important that the knowledge can be structured in the mind. When an individual encounters new information, he can make sense of the information by going through a series of mental processes. This process includes examining the incoming information, examining and relating the similarities and differences of the new information with the existing information of the individual and taking its place in the information scheme in the mind. Two of the types of knowledge in mathematics education are procedural and conceptual knowledge. Conceptual understanding is the understanding of mathematical concepts, definitions and principles of these concepts in one's mind. This is the process of reaching a relational and systematic structure by evaluating the information that a person encounters for the first time within the framework of his existing knowledge and perception. Understanding algebraic symbols is a form of conceptual understanding. Algebraic fractional equations, on the other hand, are thought to have a more complex structure in terms of being able to be represented because they have different meanings of algebraic symbols and different meanings of fractions. In this research, algebraic fractional equations are discussed both according to their types and different meanings of fractions. How students interpret these equations, what meanings they attribute to the variables, and how these meanings are related to different interpretations of fractions are examined within the scope of verbal problem posing. The aim of this research is to examine the development of students' conceptual knowledge in algebraic fractional equations. For this purpose, it was investigated how the participants' understanding of algebraic fractional equations developed. In this context, it is thought that this study will fill an important gap in the literature.

\section{Methodology:}

In this study, the changes in the cognitive structures of the participants regarding conceptual understanding on the subject of equations containing algebraic fractional expressions in a teaching process conducted by the researcher-teacher were monitored. For this reason, it was possible to shape the teaching based on their thoughts by interacting with the participants for a long time. For this purpose, the "teaching experiment" model, which is considered within the scope of qualitative research approaches, was used in the research. The model of the research is "teaching experiment", "clinical interviews" and "document review" to support this. In the determination of the participants in the study, the criterion sampling method, which is one of the purposeful sampling methods, was used as it makes it possible to study in-depth and 4 participants were determined. The obtained data were analyzed by content analysis method.

\section{Results, discussion and conclusion:}

The first result obtained in this research, which examines the change process of conceptual knowledge about equations containing algebraic fractional expressions; the most commonly used meanings in problems are fraction, ratio and measurement meanings. Students first tried to create the meaning of the fraction, then they created other dimensions of the problem. Operator and part all meanings of fraction were the least used meanings. It is thought that this situation may be due to several factors. The first of the effective factors was the interpretation of the presented topics and the problems created, although the participants did not make any other intervention during the application. Another 
factor is the problems that are presented to the participants to solve after the teaching sessions and that include different meanings of the fraction. The part-whole meaning was the least used meaning in these problems. From the point of view of the processor meaning of fraction; since the participants were asked to write a verbal problem during the application, the fact that they avoided using this meaning of fraction may have been effective in the emergence of this result.

Another result obtained from this research is that the meanings of fractions used in verbal problems written in equations containing algebraic fractional expressions are related to the type of fraction. While the meaning of processor is used only in the equation containing numerator algebraic denominator numeric fractional expressions, the meaning of division is mostly used in equations containing numerator algebraic denominator numeric fractional expressions. Measuring and part-whole meanings are used in all fraction types. Ratio meaning, on the other hand, could be used in equations containing mostly algebraic fractional expressions with numerator and denominator. No study has been found in the literature on this subject. It is thought that this result can bring a new perspective to the conceptual part of algebraic fractional expressions. In the problems created in the research, it was determined that the participants generally used verbal and daily language.

In this study, before the application started, the participants generally wrote wrong word problems in the equations containing algebraic fractional expressions, left the problems incomplete or did not write any problems at all. While it was thought that the errors of changing the notation, no questions in the word problem, using missing data, adding mathematical content, were not related to the meaning of the fraction, mixing the fractional variable with the non-fractional variable, confusion in the meaning of the variable, confusing the denominator and denominator, and not being able to associate it with daily life were found to be related to the meaning of the fraction. In addition, the errors made differ according to the meaning of the fraction. No study has been found in the literature regarding this result.

\section{Giriş}

Matematik geçmişten bu yana en yoğun içeriğe sahip olan derslerden biri olarak anılmaktadır. Matematiğin bu içeriği sayılar, işlemler, cebir, geometri, veri analizi ve olasılık olmak üzere 5 konu alanına ayrılmıştır (National Council of Teachers of Mathematics Standarts (NTCM), 2000). İçeriği en fazla olan konu alanlarından biri olan cebir; hem matematikte hem de matematik eğitiminde önemli bir yere sahiptir. Çünkü okul öncesinden üniversiteye kadar bütün sınıf düzeyleri için bir konu alanı olarak planlanmıştır (Van De Walle, Karp ve Bay-Williams, 2013). Bu nedenle matematik dersi öğretim programlarında geniş yer tutar.

$\mathrm{Bu}$ konu alanının alt öğrenme alanlarından biri ise hem denklemler konusunu hemde kesirler konusunu içinde barındıran cebirsel kesirli ifadeleri içeren denklemlerdir. NCTM'e (2011) göre öğrencilerin cebirsel ifade, denklem ve fonksiyonu anlamaları değişkenlerin çoklu anlamını öğrenmelerine bağlıdır. Bu durum kesirli ifadeleri içeren denklemlerde daha karmaşık bir hal almaktadır. Booth (1986), Boothand Watson (1990), Stacey ve MacGregor (1997b) ve Kilpatrick vd. (2001) öğrencilerin cebirsel ifadelerle mücadele ettiklerini, çünkü değişkenin anlamını anlamadıklarını ve sayıdan başka bir şey olan bir probleme verilen cevabı anlamada zorlandıklarını bulmuşlardır. Sasman, Linchevski ve Olivier (1997) cebirin öğrenciler tarafından anlaşılamamasının nedenlerini cebirin yapısı, öğrencilerin zihinsel gelişimleri, hazırbulunuşluk düzeyleri ve cebirin öğretimindeki eksiklikler olarak belirtmişlerdir.

Kesirler ise başta rasyonel sayılar olmak üzere ondalık gösterimler, oran, işlemler ve cebir gibi cebirin kendisi ve alt alanlarıla yakından ilişkilidir (Behr vd., 1983, Kieren, 1988, Saxe, vd., 2001). Olkun ve Uçar'a (2007) göre kesirler, ilkokuldaki matematik konularının çoğundan daha ağır ve karışıktır. Çünkü öğrenciler kesirleri sayı olarak algılarlar ve daha önce öğrendikleri sayılarla 
ilişkilendirmede zorlanırlar. Diğer bir durum ise yapılan araştırmaların, kesrin, yani “a/b" sembolünün birden fazla şekilde yorumlanabileceğini göstermesidir (Kieren, 1976, Behr vd., 1983, Behr vd., 1992). Bir kesirli say1, verilen problemin durumuna ve içeriğine göre, parça-bütün, bir ölçüm, bir bölüm, bir orantı ya da bir işlemci anlamını barındırabilir. Bu anlam fazlalığı öğrencilerin bu sayıları ve bu sayılara ilişkin kavramları öğrenmelerini zorlaştırmaktadır (Toluk, 2001). Parça-bütün anlamında öğrenciler verilen nesneleri parçalar ve ortaya çıkan parçaları birim bütüne göre "kesir" olarak ifade etmeyi öğrenirler (Toluk, 2001). "Ölçme durumlarında a/b gibi bir kesirle ilgileniyorsak b eşit parçaya bölünmüş herhangi bir nesnenin parçalarının a tanesinden bahsediyoruz demektir. Ölçme birimimiz 1/b'dir.” (Acar, 2010, s. 6). Buradaki asıl mevzu bir ölçme birimine sahip olmamızdır. İşlemci anlamı rasyonel sayının bir işlemin ana unsuru olduğu durumlarda söz konusudur. "Oran, iki niceliğin arasındaki ilişkidir. Oran parça-bütün kıyaslaması (kız: toplam=3:4) ya da iki farklı niceliğin kıyaslaması (1 saatte $80 \mathrm{~km}$ yol almak) şeklinde olabilir (Acar, 2010, s. 8). "Bölüm anlamı ise bir miktar çokluğun belli sayıda kişilere veya şeylere (bardaklara, sınıflara, kutulara, hayvanlara, vb.) paylaştırılması, genel olarak bir rasyonel sayının iki doğal sayının bölümünü gösterdiği daha matematiksel olarak ise bir a miktarının b tane gruba eşit olarak paylaştırıldığı durumlardır." (Acar, 2010, Alacaci, 2012).

$\mathrm{Bu}$ çalışma kapsamında cebirsel kesirli ifadeleri içeren toplama ve çıkarma işlemlerine ve bu ifadelere yüklenen anlamlara odaklanılmıştır. Cebirsel kesirler içerisinde değişken ve sabit bulunan kesirli ifadeler olarak tanımlanmıştır. Örneğin, $\frac{5 x-8}{x-3}, \frac{x+1}{2}$ veya $\frac{3}{x-2}$. Öksüz'e (2004) göre cebirsel kesirler payı cebirsel paydası nümerik (PcPdn), payı nümerik paydası cebirsel (PnPdc) ve pay ve paydası cebirsel (PcPdc) olarak 3 şekilde gösterilebilir. Bu çalışmada cebirsel kesirler kapsamında sadece birinci dereceden bir bilinmeyenli cebirsel ifadelere yer verilmiştir.

Milli Eğitim Bakanlığı (MEB) 2013 matematik öğretim programında cebir konusu 6. sınıftan itibaren başlamakta ve 8 . sinıfta en yoğun halini alarak devam etmektedir. 6 sinıfta, $a / 5,2 a / 5$ biçimindeki cebirsel ifadelerin anlaşılmasına yönelik çalışmalara yer verilmesi vurgusu yapılırken, 8 . sınıfta katsayıları rasyonel olan denklemlerin çözümüne yer verilmesi vurgusu yapılmıştır. 6. Sınıfta sözel olarak verilen bir duruma uygun cebirsel ifade ve verilen bir cebirsel ifadeye uygun sözel bir durum yazma vurgusu yapılırken, 7. sınıfta gerçek yaşam durumlarına uygun birinci dereceden bir bilinmeyenli denklemleri kurma kazanımı yer almaktadır. 9. Sınıfta ise denklem ve eşitsizlikleri günlük yaşamla ilgili problemleri çözmede kullanılması belirtilirken, problem kurma ile ilgili bir kazanım yer almamaktadır.

Cebirin anlamlı bir şekilde öğrenilebilmesi noktasında bilginin zihinde yapılandırılabilmesi önemlidir. Birey yeni bir bilgi ile karşıllaştı̆̆ında ancak bir dizi zihinsel süreçten geçerek bilgiyi anlamlandırabilir. $\mathrm{Bu}$ süreç gelen bilginin incelenmesi, yeni bilginin bireyin mevcut bilgileri ile olan benzerlik ve farklılıklarının irdelenerek ilişkilendirilmesi ve zihinde bulunan bilgi şemasında yerini almasını içerir. Bu aşamada bilginin yapısı önemli bir yere sahiptir, çünkü bu süreci doğrudan etkiler. Matematik eğitimindeki bilgi türlerinden ikisi ise işlemsel ve kavramsal bilgidir (Skemp, 1978, Yanık ve Serin, 2016). Bu bilgi türleri işlemsel anlama ve kavramsal anlama olarak da karşımıza ç1kabilmektedir.

İşlemsel bilgi problem çözmede kullanılan işlemlerin adımlarını içeren bilgidir (Star, 2005, 2007). Kavramsal bilgi "matematiksel kavramların, işlemlerin ve ilişkilerin anlaşılması" olarak ifade edilebilir (Kilparick, Swafford ve Findell, 2001, s.5). Kavramsal anlama, matematiksel kavramların, bu kavramlara ait tanımların ve ilkelerin kişinin zihninde anlam kazanmasıdır. Bu ise kişinin ilk defa karşılaştığı bir bilgiyi var olan bilgileri ve algılayışı çerçevesinde değerlendirip ilişkisel ve sistemli bir yapıya ulaşma sürecidir (Yanık, 2015). 
Crooks ve Alibali (2014) alanyazından yola çıkarak kavramsal bilgiye dair 6 kategori oluşturmuşlardır. Bunlar; Bağlantılı Bilgi (Bir etki alanı içindeki ilişkiler), Genel İlkeler Bilgisi (Genel kurallar, gerçekler ve tanımlar), Prosedürlerin Dayandığı İlkeler Bilgisi (İlkelerin temelleri), Kategori Bilgisi (Bilgiyi organize eden kategoriler), Alan Yapı Bilgisi (Matematiğin organizasyonu) ve Sembol Bilgisi'dir (Sembolün anlamları). Bu kategoriler dâhilinde bu araştırmada sembol bilgisi, yani sembollerin anlamı ele alınmıştır. Alibali vd. (2014) denklemlerde sembollerin kavramsal anlamada önemli bir yeri olduğunu ve cebirin sembollerle oluşumunun sembolleri anlamayı (Looking through) içerdiğini ifade etmişlerdir. Pope'e (1994) göre öğrencilerin denklemleri günlük hayatta farklı bir şey gibi algılamaları denklemleri anlama konusunda zorluk yaşamalarına neden olmaktadır. Gerçek yaşamla ilişkilendirme anlamında sembollerin farklı temsilleri önemli bir yere sahiptir.

Crooks ve Alibali (2014) cebirsel sembolleri anlamanın bir kavramsal anlama şekli olduğunu belirtmişlerdir. Semboller bir diyagram, bir tablo, bir sözel açıklama ya da fiziksel bir canlandırma ile ilişkilendirilebilir. Alibali vd. (2014) sembollerin tek başına verilmesinden ziyade bu referanslarla (diyagram, tablo, sözel açıklama vb.) ilişkili bir şekilde verilmesinin denklemleri anlamlı bir şekilde öğrenmek açısından önemli olduğunu vurgulamışlardır. Farklı temsiller rasyonel sayılar için de söz konusudur. Rasyonel sayılar sözel, sembolik, nesne ve model olmak üzere dört farklı biçimde gösterilebilmektedir (Birgin ve Gürbüz, 2009). Farklı temsillerin kullanımı önemlidir.

Cebirsel kesirli denklemlerin ise hem cebirsel sembollerin farklı anlamlarına hem de kesrin farklı anlamlarına sahip olması nedeniyle temsil edilebilme manasında daha karmaşık bir yapıya sahip olduğu düşünülmektedir. Bu açıdan bakıldığında, cebirsel kesirli bir ifadenin sözel hikâye gösterimi cebirsel sembollerin ve kesirlerin sözel-hikâye gösterimini bir arada içermektedir. Bu araştırmada cebirsel kesirli denklemler; günlük hayatla ilişkili sözel hikâye problemleri kapsamında kavramsal olarak incelenmiştir.

Geçmişte araştırmacılar öğrencilerden ya cebirsel bir denklemin çözümünü istemişler ya da sözel problemleri cebirsel denklemlere dönüştürmelerini istemişlerdir. Bu çalışmalar çok yapıldığı için öğrenci artık bu tür problemlere dair bir alışkanlık geliştirmiş olabilir. Sözel problemleri sembole çevirmek rutine dönüşebilir ve sadece bu görev öğrencinin kavramsal anladığını göstermez. Öğrencinin kavramsal anlayıp anlamadığını tespit etmek için yeni görevler verilmesi gerekmektedir (Alibali vd., 2014). Problem kurma öğrencilerin matematiği anlayarak öğrenmelerini sağlar (Stoyanova, 2003), matematiksel yaratıcılıklarını geliştirir (Sheffield ve Cruikshank, 2005, Van Harpen ve Sriraman, 2013) ve öğrencilerin kavram yanılgılarını anlamalarını ve gidermelerini sağlar (Ticha ve Hospesova, 2009).

Başka problem kurma sınıflandırmaları (Örneğin; Stoyanova \& Ellerton,1996) olmakla birlikte bu araştırmada Silver (1994) tarafından ifade edilen; verilen matematiksel bir ifadeye problem kurma, çözülmüş bir problemi yeniden oluşturma ya da olan bir problemi değiştirerek yeni problem kurma olarak üç şekilde belirtilen problem kurma sınıflaması kullanılmış ve katılımcılardan verilen cebirsel kesirli ifadelere sözel hikâye problemi kurmaları istenmiştir.

Problem kurmaya dair yapılan çalışmalar incelendiğinde, kümeler (Şengül ve Katranc1, 2012), geometri (Vacc, 1993 Lavy ve Bershadsky, 2003, Van Harpen ve Sriraman, 2013), olasılık (Y1ldiz ve Baltac1, 2015, Silber ve Cai, 2017), oran-orantı (Şengül ve Katranc1, 2015), mutlak değer (Güveli, 2015) ve kesirler (Toluk-Uçar, 2009, Işık, 2011, Ünlü ve Ertekin, 2012, Kılıç, 2013) konusunda çalışmalar mevcuttur. Kavramsal boyutta genellikle bir kavram üzerine odaklanılmış, değişkene ve eşitlik sembolüne yüklenen anlam ve hatalar bu çalışmaların odak noktası olmuştur (Keiran, 1981, Schoenfeld ve Arcavi, 1988, Pope, 1994, Crooks ve Alibali vd., 2014). Bu araştırmada cebirsel kesirli denklemler hem türlerine hem de kesrin farklı anlamlarına göre ele alınmıştır. Özellikle, öğrencilerin bu denklemleri nasıl yorumladıkları, değişkenlere ne gibi anlamlar yükledikleri ve bu anlamların kesirlerin farklı yorumları ile nasıl ilişkili olduğu incelenmiştir. 
$\mathrm{Bu}$ araştırmanın amacı cebirsel kesirli ifadeleri içeren denklemlerde öğrencilerin kavramsal bilgilerinin gelişimini incelemektir. Bu amaçla öğrencilerin cebirsel kesirli denklemleri anlamlandırma süreçleri incelenmiştir.

Katılımcılar cebirsel kesirli ifadeleri içeren denklemleri anlamlandırma durumları nasıl gelişmektedir?

- Katılımcılar verilen cebirsel kesirli denklemlere yönelik sözel-hikâye problemlerini uygulama öncesinde ne ölçüde yazabilmektedirler?

- Katılımcıların verilen cebirsel kesirli denklemlere sözel hikâye problemi yazabilme becerileri zamanla nasıl bir değişim göstermektedir?

İlgili alanyazında bu konuyla ilgili üç çalışma bulunabilmiştir. İlk çalışmada Alibali vd. (2014) ortaokul öğrencilerinden birinci dereceden bir bilinmeyenli denklem sorularını sözel probleme dönüştürmelerini istemişlerdir. Sonuç olarak, öğrencilerin denklemleri sözel probleme dönüştürürken çeşitli hatalar yaptıklarını belirtmişlerdir ve bu hatalar neticesinde öğrencilerin çarpma işlemi ile sembolik sunumu arasındaki bağı anlamada eksikliklerinin olduğunu ve tutarlı bir hikâye içerisinde çoklu matematiksel işlemleri göstermede zorluk yaşadıklarını belirlemişlerdir. Diğer çalışmada Ünlü ve Sarpkaya Aktaş (2017) ilköğretim matematik öğretmeni adaylarının cebirsel ifade ve denklemlere ilişkin kurdukları problemleri incelemişlerdir. Elde edilen sonuçlara göre öğretmen adaylarının cebirsel ifade ve denklemlere yönelik genel olarak sözel ve çözülebilen problemler kurdukları, kurulan problemlerde genellikle günlük dili kullandıkları tespit edilmiştir. Son çalışmada ise Öksüz (2004) cebirsel kesirlerde kesrin bölüm anlamını incelemiştir. Bu çalışmada öğrencilerin kesrin gelişim sürecinde öncelikle parça bütün anlayışına sahip oldukları daha sonra kesri paylaştırma olarak algıladıkları ve kesirler ve cebirsel kesirlerle ilgili farklı anlayışlara sahip oldukları vurgulanmıştır.

\section{Yöntem}

$\mathrm{Bu}$ araştırmada araştırmacı-öğretmen tarafından yürütülen bir öğretim sürecinde cebirsel kesirli ifadeleri içeren denklemler konusuna ilişkin katılımcıların kavramsal anlamaya dair bilişsel yapılarının değişimleri izlenmiştir. $\mathrm{Bu}$ nedenle katılımcılarla uzun süreli etkileşim içerisine girilerek onların düşüncelerine dayalı öğretimi şekillendirme söz konusu olmuştur. Bu amaç doğrultusunda araştırmada nitel araştırma yaklaşımları kapsamında ele alınan "öğretim deneyi”" (Steffe ve Thompson, 2000) modeli kullanılmıştır. Araştırmanın modelini "öğretim deneyi”, bunu desteklemek için yapılan "klinik görüşmeler" ve "doküman incelemesi” oluşturmaktadır. Öğretim deneyi Piaget’nin klinik görüşme yönteminden türetilmiş bir araştırma aracı olmakla birlikte öğretim sürecinin iyileştirilmesine yönelik deneysel bir boyut içermesi sebebiyle klinik görüşme yönteminden daha geniş ve derin incelemelerin yapıldığı bir yöntemdir (Steffe ve Thompson, 2000).

\section{Katılımcilar}

Araştırmada katılımcıların belirlenmesinde, derinlemesine çalışmayı olanaklı kıldığg için amaçlı örnekleme (Patton, 1997) yöntemlerinden ölçüt örnekleme yöntemi kullanılmıştır. Ölçüt örnekleme yönteminde, araştırma konusuna göre daha önce belirlenmiş olan ölçütleri sağlayan durumlar üzerinde derinlemesine çalışılabilmektedir (Yıldırım ve Şimşek, 2005).

Katılımcılar üç temel ölçüte göre belirlenmiştir. İlk ölçüt ön uygulama sorularının ilk bölümünde yer alan numeric kesirli işlemlerde hata yapmamalarıdır. İkinci ölçüt ön uygulama sorularının ikinci bölümündeki cebirsel kesirli ifadeleri içeren denklemlere cevap verebilmeleridir. Üçüncü ölçüt ise cebirsel ifadelere yönelik sözel problem yazmada güçlükler yaşıyor olmalarıdır. Bu üç ölçütün olmasının nedeni öğretim seansları ile yapılması planlanan uygulamanın varsa sonuçlarını daha açık bir şekilde görebilmektir. Bu sürecin sonunda 4 öğrenci (Ayşegül, Berna, Erdem ve Serkan kod isimleri 
verilmiştir) çalışmanın katılımcıları olarak belirlenmiştir. Bu katılımcılardan ikisi (Ayşegül ve Serkan) Fen Lisesi'nde, ikisi ise (Berna ve Erdem) Anadolu lisesinde öğrenim görmektedirler. Katılımcıların tamamı kesirlerde işlemleri doğru bir şekilde yapabilmişlerdir. Üç katılımcı cebirsel kesirli ifadeleri içeren denklemlere çözümler geliştirebilmiştir. Katılımcıların tamamı verilen denklemlerin sadece bazılarına problem yazabilmişlerdir.

\section{Veri toplama yöntemleri ve araçları}

Çalışma kapsamında veriler; görüşmeler, bireysel gözlemler (alan notları) ve doküman incelemesi yoluyla toplanmıştır. Öncelikle katılımcılarla ilk klinik görüşmeler yapılmış ardından birer hafta ara ile ögretim seansları uygulanmış (toplam yedi hafta) ve son aşamada başlangıçta yapılan klinik görüşme ögretim seanslarından 1 hafta sonra yeniden uygulanmıştır. Yaklaşık 3 aylık bir geri çekilme sürecinin ardından kalıcılık klinik görüşmesi gerçekleştirilmiştir.

Çalışmada yapılan bireysel görüşmeler ön ve son görüşmeler (yapılandırılmış), öğretim seansları sonunda yapılan görüşmeler (yarı-yapılandırılmış) ve kalıcılık görüşmeleri (yapılandırılmış) şeklinde sınıflandırılmıştır. Katılımcılar öğretim seansları boyunca araştırmacı tarafından gözlemlenmiştir. Araştırmac1 öğretim seansları boyunca araştırmacı-öğretmen rolü üstlenerek öğrencilerin sorulara verdikleri yanıtları ve düşünce yapılarını anlamaya çalışmıştır. Gözlemler araştırmacının tuttuğu alan notları ve video kayıtları yoluyla tutulmuş ve her öğretim seansının sonunda dökümü yapılan video kayıtları ve tutulan alan notları karşılaştırılarak sürecin nasıl geliştiği anlaşılmaya çalışılmıştır. Çalışma kapsamındaki bireysel öğretim seanslarının amacı, katılımcıların düşüncelerini değiştirmeye teşvik edecek ortamlar yaratarak, onların değişen kavramsal yapılarını derinlemesine incelemektir. $\mathrm{Bu}$ kapsamda araştırmacı her bir katılımcı ile ayrı ayrı haftada bir kere bir araya gelerek ortalama $150 \mathrm{dk}$ süresince öğretim seanslarını gerçekleştirmiş̧tir (bkz. Tablo 1). Katılımcıların problem kurma sürecinde farklı düşünebilmeleri ve farklı problemler yazabilmeleri amacıyla kesrin farklı anlamlarını içerebilecek problem konuları katılımcılara sunulmuştur. Ardından sözel problem verilerek katılımcılardan probleme uygun denklemi yazmaları istenmiştir.

Tablo 1. Katılımcılara cebirsel kesirli ifadeleri içeren denklemlere problem yazmaları için tasarlanan öğretim seansları

\begin{tabular}{|c|c|c|}
\hline Öğretim seans1 & İçerik & Amaç \\
\hline Öğretim seans1 1 & $\begin{array}{l}\text { Pc Pdn kesirli ifadeler bulunan, toplama } \\
\text { ve çıarma işlemi içeren denklemler }\end{array}$ & $\begin{array}{l}\text { Verilen denkleme kesrin bölüm anlamın } \\
\text { içeren problem yazabilme düzeyleri ve gelişim } \\
\text { süreci }\end{array}$ \\
\hline Öğretim seans 2 & $\begin{array}{l}\text { Pc Pdn kesirli ifadeler bulunan, toplama } \\
\text { ve çıarma işlemi içeren denklemler }\end{array}$ & $\begin{array}{l}\text { Verilen denkleme kesrin ölçme ve işlemci } \\
\text { anlamını içeren problem yazabilme düzeyleri } \\
\text { ve gelişim süreci }\end{array}$ \\
\hline Öğretim seans 13 & $\begin{array}{l}\text { Pc Pdn kesirli ifadeler bulunan, toplama } \\
\text { ve çıarma işlemi içeren denklemler }\end{array}$ & $\begin{array}{l}\text { Verilen denkleme kesrin oran ve parça-bütün } \\
\text { anlamını içeren problem yazabilme düzeyleri } \\
\text { ve gelişim süreci }\end{array}$ \\
\hline Öğretim seans 14 & $\begin{array}{l}\text { Pn Pdc kesirli ifadeler bulunan, toplama } \\
\text { ve çıarma işlemi içeren denklemler }\end{array}$ & $\begin{array}{l}\text { Verilen denkleme kesrin bölüm anlamını ve } \\
\text { ölçme anlamını içeren problem yazabilme } \\
\text { düzeyleri ve gelişim süreci }\end{array}$ \\
\hline Öğretim seans1 5 & $\begin{array}{l}\text { Pn Pdc kesirli ifadeler bulunan, toplama } \\
\text { ve çıarma işlemi içeren denklemler }\end{array}$ & $\begin{array}{l}\text { Verilen denkleme kesrin oran anlamını işlemci } \\
\text { anlamını ve parça-bütün anlamını içeren } \\
\text { problem yazabilme düzeyleri ve gelişim süreci }\end{array}$ \\
\hline
\end{tabular}


Tablo 1'in Devamı. Katılımcılara cebirsel kesirli ifadeleri içeren denklemlere problem yazmaları için tasarlanan öğretim seansları

\begin{tabular}{lll}
\hline Öğretim seansı 6 & $\begin{array}{l}\text { Pc Pdc kesirli ifadeler bulunan, toplama } \\
\text { ve çıarma işlemi içeren denklemler }\end{array}$ & $\begin{array}{l}\text { Verilen denkleme kesrin bölüm anlamını ve } \\
\text { parça-bütün anlamını içeren problem } \\
\text { yazabilme düzeyleri ve gelişim süreci }\end{array}$ \\
Öğretim seans1 7 & $\begin{array}{l}\text { Pc Pdc kesirli ifadeler bulunan, toplama } \\
\text { ve çıarma işlemi içeren denklemler }\end{array}$ & $\begin{array}{l}\text { Verilen denkleme kesrin ölçme anlamını, } \\
\text { işlemci anlamını ve oran anlamını içeren } \\
\text { problem yazabilme düzeyleri ve gelişim süreci }\end{array}$
\end{tabular}

\section{Verilerin analizi}

Toplanan nitel veriler içerik analizi yöntemiyle analiz edilmiştir. Öncelikle video çözümlemeleri, uygulama kâğıtları, araştırmacı-öğretmenin almış olduğu alan notları ve katılımcıların günlükleri her uygulama için incelenmiştir. Yazılan problemler hem doğru, yanlış ya da eksik olma durumuna göre hem de kesrin farklı anlamlarına göre irdelenmiştir. Ayrıca problem yazarken yapılan hatalar alanyazında mevcut olan hata türleri (Alibali vd., 2014, Ünlü ve Sarpkaya Aktaş, 2017 vb.) ve araştırmacılar tarafından belirlenen hata türleri kapsamında belirlenmiştir. Dikkat edilen diğer bir durum ise problemin sözel, sözel-matematiksel ya da matematiksel olup olmadığıdır. Eğer bir problem günlük hayatla ilişkili ve hikâyeleştirilerek kurulmuşsa sözel, hikâyeleştirilememişse matematiksel, bu ikisi arasında kalmış ise sözel matematiksel olarak kodlanmıştır (Ünlü ve Sarpkaya Aktaş, 2017).

\section{Araştırmanın Geçerliliği ve Güvenilirliği}

$\mathrm{Bu}$ araştırmanın inandırıcılığını sağlamak amacıyla katılımcılarla uzun süreli etkileşim sağlanmış ve uygulama esnasında katılımcılara herhangi bir zaman sınırlaması getirilmemiş ve not verilmemiştir. Farklı veri toplama araçları ile çeşitleme (triangulation) yapılmış ve katılımcıların günlüklerinde ifade ettikleri verilen denkleme problem yazabilme durumlarına dair yorumların araştırmacı-öğretmenin alan notlarından, video kayıtlarından ve uygulama kâğıtlarından kontrol edilmesi yoluyla elde edilen verinin inandırıcılığ 1 arttırılmıştır. Araştırmada verinin doğasına sadık kalınarak ayrıntılı betimlemeler ve doğrudan alıntılarla aktarılabilirlik sağlanmıştır. Araştırma tutarlık ve teyit incelemesinin sağlanması için farklı iki matematik eğitimcisi tarafından veriler ve kodlamalar incelenmiştir. Katılımcıların görüsslerinden bölümlerin sunulması ise güvenirlik konusuna 1şık tutmaktadır. Ayrıca çözdürülen denklemler, olası çözümler açısından ve yazılan problemler, kullanılan kesir anlamı açısından farklı iki matematik eğitimcisi araştırmacı tarafından incelenerek görüş birliği sağlanmaya çalışılmıştır. Öncelikle yazılan problemler araştırmacılar tarafından incelenerek "Görüş Birliği" ve "Görüş Ayrılı̆̆ı" olan maddeler belirlenmiştir. Araştırmanın güvenirliğinde Miles ile Huberman'ın (1994) (Uzlaşma Yüzdesi) $=[\mathrm{Na}($ Görüş Birliği) / Na (Görüş Birliği) + Nd (Görüş Ayrılı̆̆ı) $]$ X 100 formülü aracılığıyla belirlenmiş ve uzlaşma \% 94 bulunarak bu araştırmanın güvenilir olduğu kabul edilmiştir.

\section{Bulgular}

$\mathrm{Bu}$ bölümde katılımcıların cebirsel kesirli ifadeleri içeren denklemlere dair kavramsal bilgi durumlarının öğretim seansları öncesinde (İlk klinik görüşme) , 7 seanstan oluşan öğretim seansları boyunca, öğretim seansları sonunda (Son klinik görüşme) ve yaklaşık 3 ay sonra (Kalıcılık klinik görüşme) ne düzeyde olduklarına dair bulgular yer almaktadır. Bütün uygulamalardan elde edilen veriler; katılımcılar tarafindan cebirsel kesirli ifadeleri içeren denklemlere verilen kesrin anlamları, yazılan problemin sözel olup olmadığı ve yapılan hatalar kapsamında incelenmiştir. 
İlk klinik görüşmede; katılımcılara 6 farklı denklem sunulmuş ve bu denklemlere sözel problem yazmaları istenmiştir. Katılımcıların kendilerine verilen denklemlerin çok azına $(\% 38,46)$ doğru sözel problem yazabildikleri belirlenmiştir. Yanlış yazdıkları problemlerde en fazla kesirli olmayan denklem gibi davranma gözlenirken $(\% 50,00)$, pay-payda karıştırma $(\% 12,50)$, eksik notasyon $(\% 12,50)$, denklemi değiştirme $(\% 12,50)$ ve nümerik ifade ile cebirsel ifadeyi karıştırma $(\% 12,50)$ gibi hatalarda mevcuttur. Katılımcıların boş bıraktıkları denklemler daha çok paydası cebirsel olan Pn Pdc ya da Pc Pdc kesirli ifadeleri içeren denklemler olmuştur. Yazılan problemlere en fazla kesrin bölüm anlamı $(\% 58,33)$ verilebilmekle birlikte kesrin işlemci anlamı (\%0) dışında diğer anlamlar (Oran $(\% 16,66)$, parça bütün $(\% 16,66)$, Ölçme $(\% 8,33))$ da kullanılmaya çalışılmıştır. Yazılmaya çalışılan problemlerin tamamının sözel olduğu belirlenmiştir.
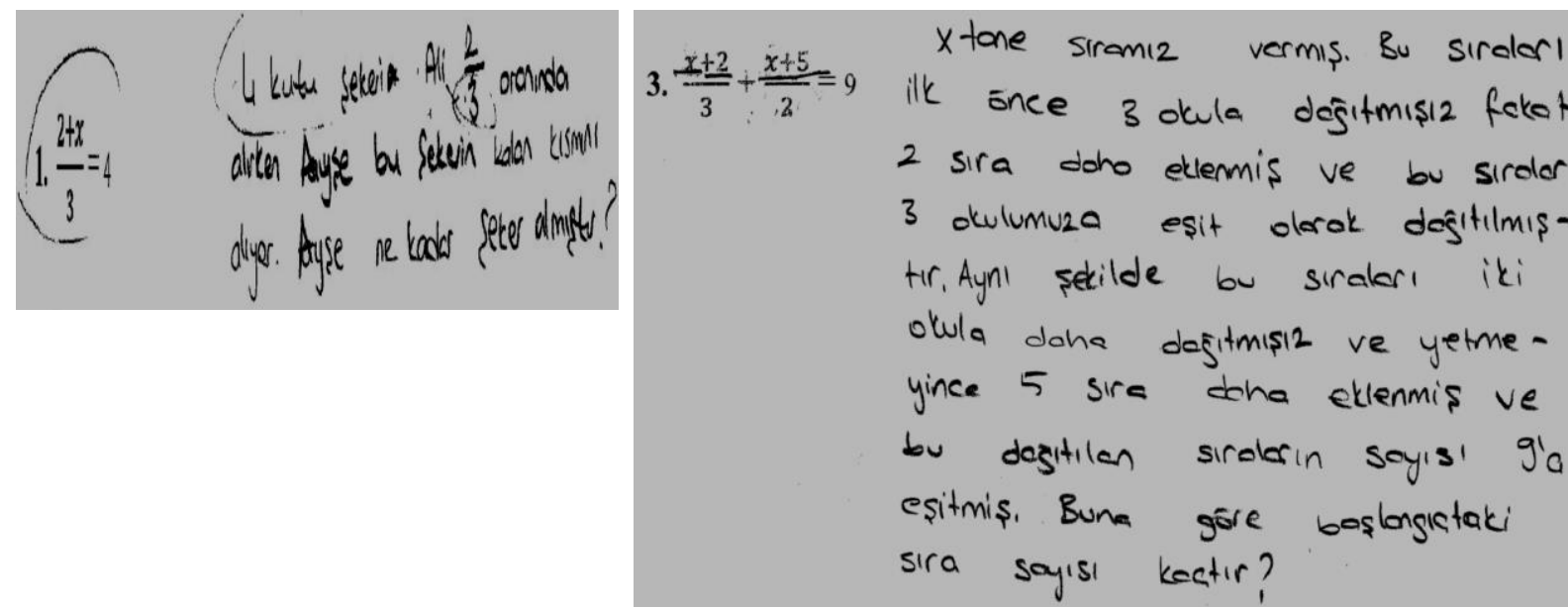

Ayşegül, İlk klinik görüşme, parça- bütün anlamı, Yanlış, Nümerik ifade ile cebirsel

Berna, İlk klinik görüşme, Bölüm anlamı, Yanlış, Kesirli ifadeyi karıştırma değişkenle kesirli olmayan değişkeni karıştırma

Şekil 1. Ayşegül ve Berna’ya ait problem örnekleri

Ayşegül probleminde belirli bir kısmını alma ifadesini kullanmış ve kesrin parça-bütün anlamını vermeye çalışmıştır. "Ali 2/3 oranında alırken Ayşse kalan kısmını almıştır..." şeklinde belirterek 2/3 nümerik ifadesini $2 \mathrm{x} / 3$ olarak probleminde ifade etmiştir. Ayrıca problemin başlangıcında bütünü 4 kutu şeker olarak ifade etmiştir. Ancak problemine bakıldığında x'i bütün olarak ele almıştır. Berna ise problemleminde bölüm anlamını dağıtma ifadesi ile kullanmaya çalışmıştır. Ancak problemindeki sözel ifadenin her bir bölüme düşen nesne sayısını ifade etmesi gerekirken, toplam nesne sayısını göstermektedir. Berna paylaşmayı ifade ederek kesrin bölüm anlamını probleminde kullanabilmiştir. Berna'nın kesirli denklemi kesirli olmayan denklem olarak ifade ederek problemini yanlış yazdığ belirlenmiştir. 


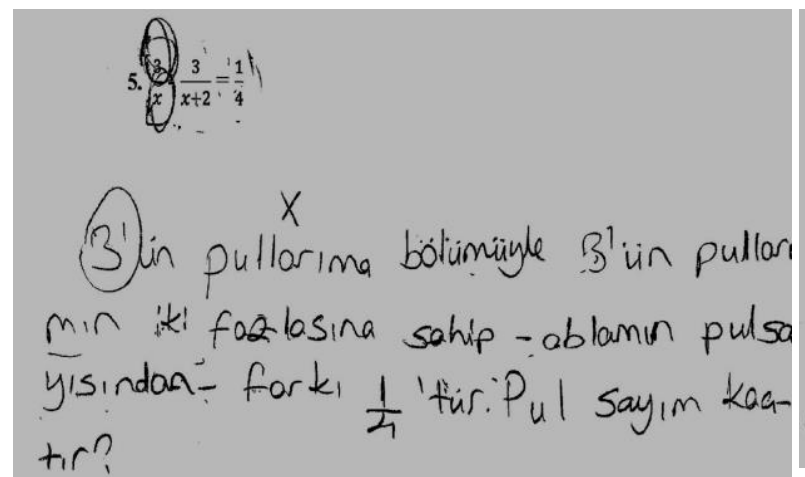

Erdem, İlk klinik görüşme, Bölüm anlamı, Yanlış, Kesirli değişkenle kesirli olmayan değişkeni karıştırma

Şekil 2. Erdem'e ait problem örnekleri

Erdem doğrudan bölme ifadesini kullanarak yazdığı problemde kesrin bölüm anlamını kullanmaya çalışmıştır. Ancak denklemde bulunan ikinci cebirsel kesirli ifadeyi sadece $x+2$ şeklinde probleminde ele almış ve kesirli değişkenle kesirli olmayan değișkeni karıștırmıştır. Diğer probleminde Erdem kesirlerin pay kısmında bulunan 90 ve 70 sayılarını "dedemin ve anneannemin yassı" olarak ifade etmesine rağmen probleminde 90 ve 70 'i kullanmamıştır. Bu nedenle eksik veri kullanma hatası yapmıştır. Serkan probleminde "kaç grup?" sorusunu cevaplayabilen bir problem yazmaya çalışmış ve kesrin ölçme anlamını kullanmıştır ancak "öğrencileri 4'erli 3 gruba ayırma" ifadesi $\frac{x+2}{4}=3$ denklemini karşılamaktadır. Bu durumda Serkan’ın denklemi değiştirerek notasyon hatası yaptığı görülmüştür.

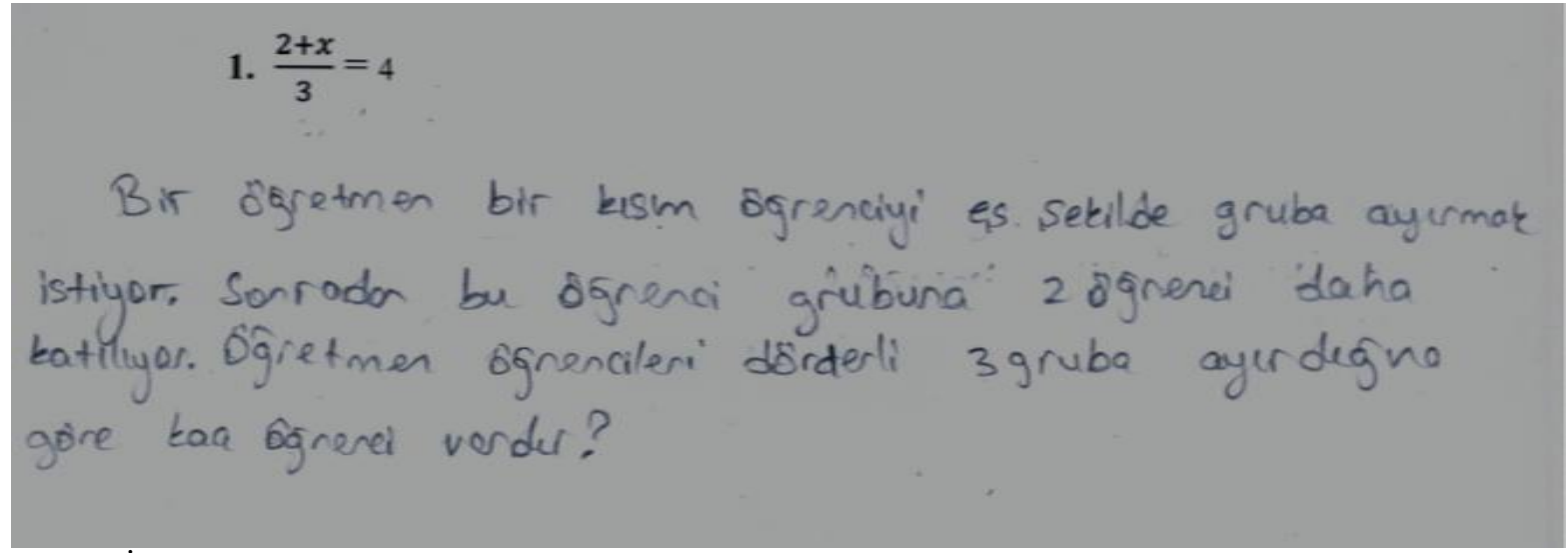

Serkan, İlk klinik görüşme, ölçme anlamı, yanlış notasyon

Şekil 3. Serkan'a ait problem örnekleri

Klinik görüşmelerin ardından elde edilen bulgulara göre tasarlanan, ortak sorular olmakla birlikte katılımcının durumuna göre farklı sorularında mevcut olduğu ögretim seanslarında, katılımcıların cebirsel kesirli denklemlere dair kavramsal değişim süreçleri ele alınmıştır. Elde edilen verilere göre problemler genellikle doğru $(\% 69,59)$ ve sözel $(\% 93,91)$ olarak yazılabilmiştir. Ancak eksik $(\% 6,08)$ ya da yanlış $(\% 24,32)$ yazılmış problemler ya da tamamen boş bırakılmış $(\% 1,35)$ denklemler de mevcuttur. Eksik bırakılma durumu ise bütün kesir türlerinde yapılmıştır. Yazılan problemlerin çoğu kesrin bir anlamını içermekle birlikte eksik problemler arasında anlam verilebilen yada anlam 
verilemeden eksik bırakılmış problemler de bulunmaktadır. Problemlerin doğruluğu öğretim seansları ilerledikçe artış gösterirken yanlışlığı da azalmıştır. Yanlış yazdıkları problemlerde en fazla denklemi değiştirme $(\% 60,60)$ hatası görülürken, değişkenin anlamını karıştırma $(\% 15,15)$, pay payda karıştırma $(\% 9,09)$, soru olmaması $(\% 6,06)$, kesirli olmayan denklem gibi davranma $(\% 6,06)$ ve içerik ekleme $(\% 3,03)$ gibi hatalarda mevcuttur.

Kesir türleri açısından bakıldığında; PcPdn kesirli ifadeleri içeren denklemlere yazılan problemlerin çoğu doğru $(\% 63,23)$ olmakla birlikte eksik $(\% 5,88)$ ve yanlış $(\% 30,88)$ olanlarda mevcuttur. Katılımcıların PnPdc kesirli ifadeleri içeren denklemlere yazdıkları problemlere bakıldığında; \%73,68'inin doğru, \%7,89'unun eksik, \%18,42'sinin yanlış olduğu belirlenmiştir. PcPdc kesirli ifadeleri içeren denklemlerde yazılan problemlerin büyük bir kısmının doğru $(\% 76,19)$, geri kalanlarının ise eksik $(\% 4,76)$ ve yanlış $(\% 19,04)$ yazıldığı görülmüştür. Kesir türleri kapsamında kendi içerisinde en yüksek oranda doğru problemin PcPdc kesirli ifadeleri içeren denklemlerde yazılabildiği görülürken, en yüksek oranda yanlış problemin ise PcPdn kesirli ifadeleri içeren denklemlerde yazıldığı görülmüştür. En çok eksik bırakılan problemin ise PnPdc kesirli ifadeleri içeren denklemlerde olduğu görülmüştür. Öğretim seansları ilerledikçe doğru oranı artmakla birlikte, ilk defa paydası cebirsel ifadelere problem yazma görevlerinin verildiği PnPdc kesirli ifadeleri içeren denklemlere yazılan problemlerde yüksek oranda eksik bırakılan problemin olduğu belirlenmiştir.

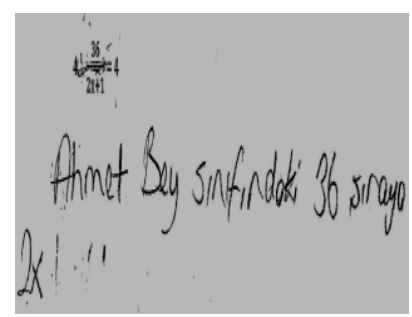

Erdem, Öğretim seans1 4, Eksik problem, sözelmatematiksel dil, Bölüm anlamı

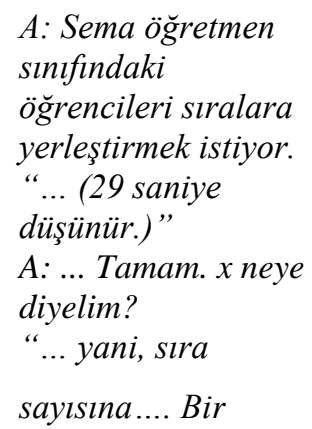

A: Sema ögretmen sinifindaki ögrencileri siralara yerleştirmek istiyor. “... (29 saniye düşünür.)” A: ... Tamam. x neye diyelim? “... yani, stra saylsina.... Bir straya oturabilecek kişiye mi?

Erdem'in Yorumu

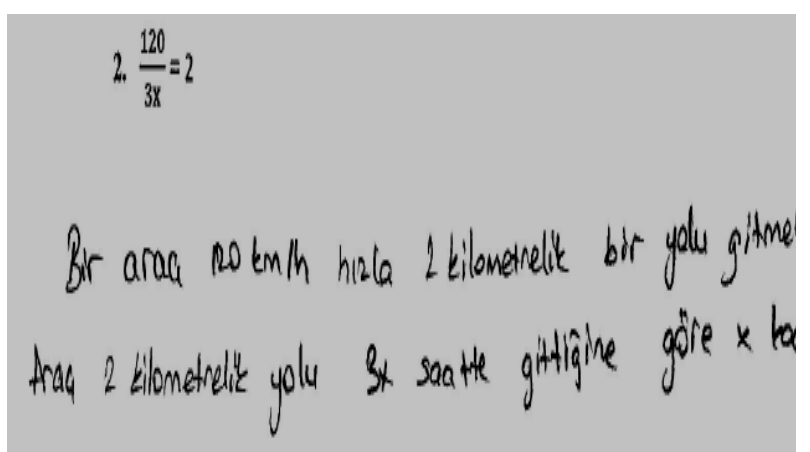

Serkan, Öğretim seansı 4, Oran anlamı, Sözelmatematiksel dil, denklemi değiştirme, pay- payda karışımı

Şekil 4. Erdem ve Serkan'a ait problem örnekleri

Eksik bırakılan soruda araştırmacı-öğretmen tarafından Erdem'e problem konusu verilmiş ve Erdem bu problem konusunu kullanarak kesrin bölüm anlamını verebilmiş, ancak değişkenin ne ifade edeceğini belirleyememiştir. Nitekim değişkeni $2 \mathrm{x}$ olarak probleminde ifade etmiş ve sözel dil ile matematiksel dili bir arada kullanmıştır. Serkan probleminde yolu ve hızı birbirine oranlayarak zamanı ifade etmiş ve kesrin oran anlamını kullanmıştır. Ancak Serkan'ın oluşturduğu yanlış problem ele alındığında, öncelikle 2 kesrin payda kısmında $3 \mathrm{x}$ eşitliğin karşı tarafında gibi ifade ederek denklemi değiştirmiştir. Diğer taraftan hızın, yolun ve saatin birimlerini karıştırarak pay ve paydada da bir karmaşa yaşamıştır. Ayrıca bilinmeyeni x şeklinde ifade ederek günlük dil ve matematiksel dili bir arada kullanmıştır.

Kesrin anlamları açısından baktığımızda; tablo 2'de göre en çok kesrin bölüm anlamına dair $(\% 46,20)$ problem yazılabilmiştir. Kesrin işlemci $(\% 4,82)$ ve parça-bütün anlamı $(\% 4,82)$ ise en az 
verilen anlamlar olmuştur. Kesrin farklı anlamlarına dair problem yazılabilme durumları kesir türlerine göre değişiklikler göstermektedir.

Tablo 2. Katılımcıların öğretim seanslarında verilen denklemlere cebirsel kesir türüne göre problem yazabilme durumları

\begin{tabular}{lcccc}
\hline Kesrin anlam1 & PcPdn & PnPdc & PcPdc & Toplam \\
\hline Bölüm & 47 & 13 & 7 & 67 \\
Oran & 2 & 12 & 19 & 33 \\
Ölçme & 8 & 10 & 13 & 31 \\
İşlemci & 7 & 0 & 0 & 7 \\
Parça Bütün & 2 & 2 & 3 & 7 \\
Toplam & 66 & 37 & 42 & 145 \\
\hline
\end{tabular}

Kesrin bölüm anlamı en çok $(\% 70,14)$ PcPdn kesirli ifadelerde ortaya çıkarken, kesrin oran anlamı $(\% 57,57)$ ve ölçme anlamı en çok $(\% 41,93)$ PcPdc kesirli ifadeleri içeren denklemlerde ortaya çıkmaktadır. Kesrin oran anlamı paydası cebirsel olan ifadelerde daha yoğun ortaya çıkmıştır. Kesrin ölçme anlamına dair yazılabilen problem sayıları PcPdn olan kesir türünde en az iken, PnPdc olan kesir türüne doğru bir artış göstererek, PcPdc kesir türünde en çok kullanılan anlamlardan biri olmuştur. İşlemci anlamı sadece PcPdn kesirli ifadeleri içeren denklemlerde görülürken, parça bütün anlamı PcPdc kesir türünde daha fazla $(\% 42,85)$ ortaya çıkmakla birlikte bütün kesir türlerinde yaklaşık sayılarda yazılabilmiştir.

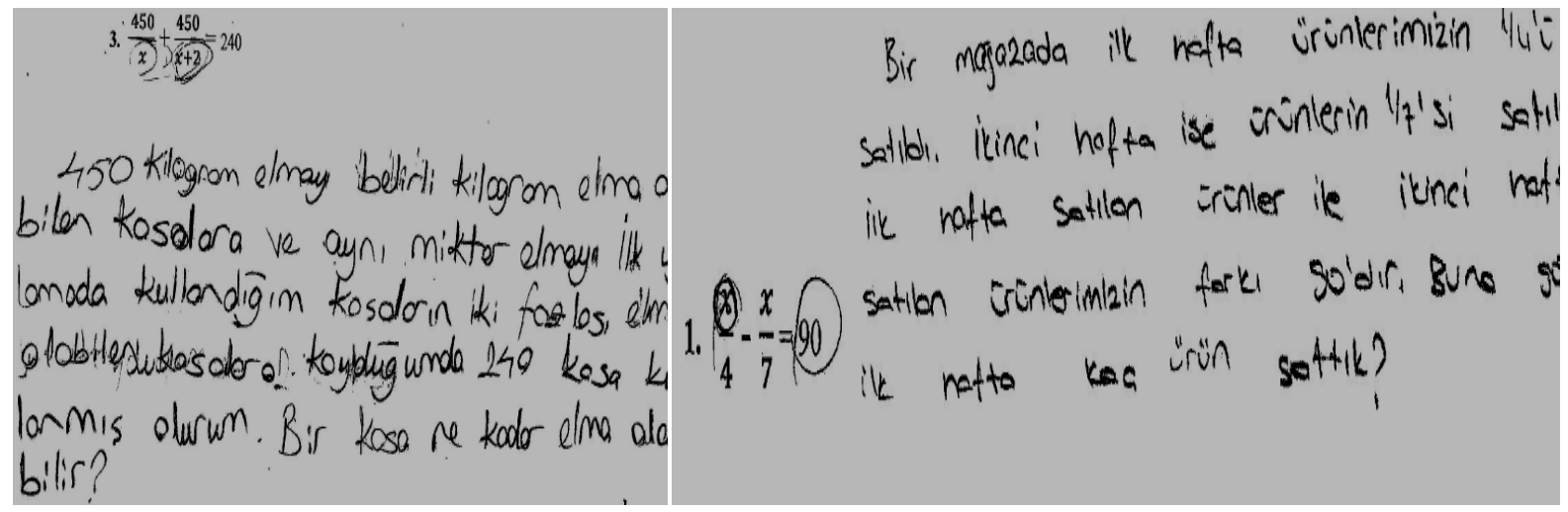

Erdem, Öğretim seansı 5, Ölçme anlamı

Berna, Öğretim seansı 3, İşlemci anlamı

Şekil 5. Erdem ve Berna'ya dair problem örnekleri

Erdem probleminde elmalarını belli miktarda elma alabilen kasalara boşaltarak kaç kasa kullandığını belirtmiş ve kesrin ölçme anlamını kullanmıştır. Berna probleminde "ürünlerin 1/4'ü" ifadesini kullanarak 1/4'ü işlemin bir parçası olarak kullanmıştır. Bu esnada araştırmacı-öğretmenin herhangi bir müdahalesi olmamıştır (bkz. Şekil 4). 


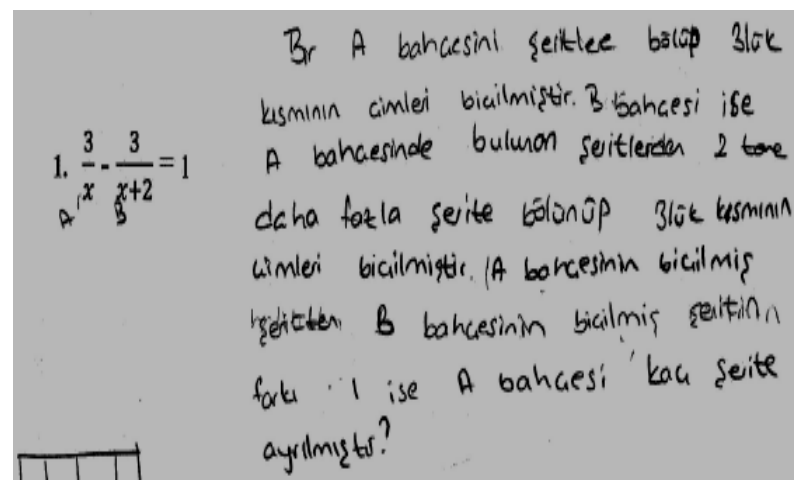

Ayşegül, Öğretim seansı 5, Parça-Bütün anlamı

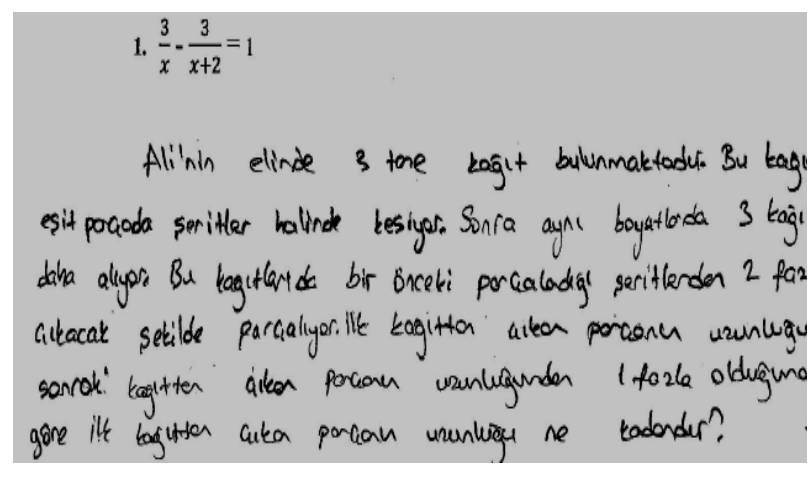

Serkan, Öğretim seansı 5, Parça-Bütün anlamı

Şekil 6. Ayşegül ve Serkan'a dair problem örnekleri

Şekil 6'da Ayşegül probleminde bahçeyi parçalara ayırıp içinden belli bir kısmının çimlerini biçerek kesrin parça bütün anlamını kullanmıştır. Serkan ise kâğıtları parçaya ayırarak kesrin parçabütün anlamını probleminde vurgulamıştır. Son olarak Tablo 3'te cebirsel kesirli ifadeler bulunan ve toplama-çıkarma işlemi içeren denklemlerden oluşan öğretim seanslarında çözdürülen problem frekansları sunulmuştur.

Tablo 3. Kesrin anlamlarına göre çözdürülen problem frekansları

\begin{tabular}{lcccccccc}
\hline & $\begin{array}{c}\text { Öğretim } \\
\text { seans1 1 }\end{array}$ & $\begin{array}{c}\text { Öğretim } \\
\text { seans1 2 }\end{array}$ & $\begin{array}{c}\text { Öğretim } \\
\text { seans1 3 }\end{array}$ & $\begin{array}{c}\text { Öğretim } \\
\text { seans1 4 }\end{array}$ & $\begin{array}{c}\text { Öğretim } \\
\text { seans1 5 }\end{array}$ & $\begin{array}{c}\text { Öğretim } \\
\text { seans1 6 }\end{array}$ & $\begin{array}{c}\text { Öğretim } \\
\text { seans1 7 }\end{array}$ & Toplam \\
\hline $\begin{array}{l}\text { Bölüm } \\
\text { anlamı }\end{array}$ & 2 & 2 & 0 & 1 & 0 & 1 & 1 & 7 \\
$\begin{array}{l}\text { Oran } \\
\text { anlam1 }\end{array}$ & 0 & 0 & 0 & 1 & 1 & 3 & 1 & 6 \\
$\begin{array}{l}\text { Ölçme } \\
\text { anlam1 }\end{array}$ & 1 & 2 & 2 & 2 & 2 & 0 & 1 & 10 \\
$\begin{array}{l}\text { İşlemci } \\
\text { anlam1 }\end{array}$ & 1 & 0 & 2 & 0 & 0 & 0 & 0 & 3 \\
$\begin{array}{l}\text { Parça } \\
\text { bütün }\end{array}$ & 0 & 0 & 0 & 0 & 1 & 0 & 1 & 2 \\
$\begin{array}{l}\text { anlam1 } \\
\text { Toplam }\end{array}$ & 4 & 4 & 4 & 4 & 4 & 4 & 4 & 28 \\
\hline
\end{tabular}

Kesrin bölüm anlamı ve ölçme anlamına dair bütün kesir türlerini içeren denklemlerde problem çözdürülürken Pc Pdn kesirli ifadeleri içeren denklemlerde kesrin oran ve parça bütün anlamına dair problem çözdürülmemiştir. Kesrin işlemci anlamına dair ise Pc Pdn kesirli ifadeleri içeren denklemler dişında problem çözdürülmemiştir.

Uygulama sonrasında, son klinik görüşmede ve yaklaşık 3 ay sonra gerçekleştirilen kalıc1lık klinik görüşmede katılımcılara ilk klinik görüşmede uygulanan 6 farklı denklem sunulmuş ve bu denklemlere sözel problem yazmaları istenmiştir. Son klinik görüşmede katılımcıların kendilerine verilen denklemlerin çoğuna doğru sözel problem $(\% 88,88)$ yazabildikleri belirlenmiştir. Yanlış yazdıkları $(\% 6,66)$ problemlerde gerçeğe uygunluk ve notasyon hataları tespit edilmiştir. Gerçeğe uygunluk hatası Pn Pdc kesirli ifadeleri içeren denklemlerde görülürken, denklemi değiştirme hatası Pc Pdn ve Pc Pdc kesirli ifadeleri içeren denklemlerde görülmüştür. Ayrıca eksik bıraktıkları problemlerde $(\% 4,44)$ mevcuttur. İçerdikleri kesir türüne göre denklemlere yazılan problem sayısına oran olarak bakıldığında Pc Pdn kesirli ifadeleri içeren denklemlere 2,00 problem, Pn Pdc kesirli ifadeleri içeren denklemlere 
1,62 problem ve Pc Pdc kesirleri içeren denklemlere 2,00 problem yazabilmişlerdir. Yazılan problemlerin genellikle sözel olduğu belirlenmiştir.

Kalıcılık klinik görüşmede katılımcıların problemleri genellikle doğru $(\% 92,30)$ yazdıkları görülmüştür. Yaptıkları yanlışlardak $(\% 5,12)$ hataların ise son klinik görüşmeye benzer şekilde gerçeğe uygunluk ve denklemi değiştirme hataları olduğu belirlenirken, eksik bırakılmış problem de $(\% 2,56)$ mevcuttur. Katılımcılar en çok problemi Pc Pdn kesirli ifadeleri içeren denklemlere yazabilmişlerdir. İçerdikleri kesir türüne göre denklemlere yazılan problem sayısına oran olarak bakıldığında payı cebirsel paydası nümerik kesirleri içeren denklemlere 7,33 problem, Pn Pdc kesirli ifadeleri içeren denklemlere 6,00 problem ve Pc Pdc kesirleri içeren denklemlere 5,00 problem yazabilmişlerdir. Farklı kesir türlerini içeren denklemlerde, denklem başına yazılan problemlere bakıldığında Pc Pdn kesirli ifadeleri içeren denklemlere denklem başına yazılan problemlerin en fazla, Pc Pdc kesirli ifadeleri içeren denklemlere yazılan problemlerin ise en az olduğu belirlenmiştir.

Tablo 4. Katılımcıların Son Klinik Görüşmede ve Kalıcılık Klinik Görüşmede Yazdıkları Problemlere Verdikleri Kesrin Anlamları

\begin{tabular}{|c|c|c|c|c|}
\hline & \multicolumn{4}{|c|}{ Son Klinik Görüşme } \\
\hline \multirow[b]{2}{*}{ Katılımcılar } & \multicolumn{3}{|l|}{ Kesir Türleri } & Kesrin Anlam 1 \\
\hline & PcPdn & PnPdc & $\mathrm{PcPdc}$ & Toplam \\
\hline \multirow[t]{4}{*}{ Ayşegül } & 2 Bölüm & 1 Bölüm & \multirow[t]{4}{*}{2 Ölçme } & 3 Bölüm \\
\hline & 2 Ölçme & 2 Oran & & 4 Ölçme \\
\hline & 1 Oran & & & 3 Oran \\
\hline & 1İşlemci & & & 1 İşlemci \\
\hline \multirow[t]{4}{*}{ Berna } & 1 Bölüm & 1 Bölüm & \multirow[t]{4}{*}{1 Ölçme } & 2 Bölüm \\
\hline & 2 Ölçme & 2 Oran & & 3 Ölçme \\
\hline & 1 Oran & & & 3 Oran \\
\hline & 1Parça-bütün & & & 1Parça- bütün \\
\hline \multirow[t]{4}{*}{ Erdem } & 1 Bölüm & 3 Ölçme & \multirow[t]{4}{*}{1 Ölçme } & 1 Bölüm \\
\hline & 2 Ölçme & 1 Oran & & 6 Ölçme \\
\hline & 1 Oran & & & 2 Oran \\
\hline & 2 İşlemci & & & 2 İşlemci \\
\hline \multirow[t]{4}{*}{ Serkan } & 1 Bölüm & 1 Bölüm & \multirow[t]{4}{*}{2 Ölçme } & 2 Bölüm \\
\hline & 4 Ölçme & 1 Ölçme & & 7 Ölçme \\
\hline & 1 Oran & 1 Oran & & 2 Oran \\
\hline & 1 İşlemci & & & 1 İşlemci \\
\hline \multirow[t]{7}{*}{ Toplam } & 5 Bölüm & 3 Bölüm & \multirow[t]{5}{*}{6 Ölçme } & 8 Bölüm \\
\hline & 10 Ölçme & 1 Ölçme & & 20 Ölçme \\
\hline & 4Oran & 6 Oran & & 10 Oran \\
\hline & 4İşlemci & & & 4 İşlemci \\
\hline & 1Parça-Bütün & & & 1Parça-Bütün \\
\hline & \multicolumn{4}{|c|}{ Kalıcılık Klinik Görüşme } \\
\hline & \multicolumn{3}{|l|}{ Kesir Türleri } & Kesrin Anlamı \\
\hline Katılimcılar & PcPdn & PnPdc & PcPdc & Toplam \\
\hline \multirow[t]{5}{*}{ Ayşegül } & 2 Bölüm & 2 Bölüm & 1 Bölüm & 5 Bölüm \\
\hline & 1 Ölçme & 1 Oran & 1 Oran & 1 Ölçme \\
\hline & 1 Oran & 1Parça-bütün & & 3 Oran \\
\hline & 1 İşlemci & & & 1 İşlemci \\
\hline & & & & 1Parça-bütün \\
\hline \multirow[t]{3}{*}{ Berna } & 2 Bölüm & 2 Oran & 1 Ölçme & 2 Bölüm \\
\hline & 1 Ölçme & & & 2 Ölçme \\
\hline & 1 Oran & & & 3 Oran \\
\hline
\end{tabular}


Tablo 4.'ün devamı Katılımcıların Son Klinik Görüşmede ve Kalıcılık Klinik Görüşmede Yazdıkları Problemlere Verdikleri Kesrin Anlamları

\begin{tabular}{|c|c|c|c|c|}
\hline \multirow[b]{2}{*}{ Kat1lımcilar } & \multicolumn{4}{|c|}{ Kalıcılık Klinik Görüşme } \\
\hline & Kesir Türleri & & & Kesrin Anlamı \\
\hline Erdem & $\begin{array}{l}1 \text { Bölüm } \\
4 \text { Ölçme } \\
1 \text { İşlemci }\end{array}$ & $\begin{array}{l}1 \text { Ölçme } \\
2 \text { Oran }\end{array}$ & 1 Oran & $\begin{array}{l}1 \text { Bölüm } \\
5 \text { Ölçme } \\
3 \text { Oran } \\
1 \text { İşlemci }\end{array}$ \\
\hline Serkan & $\begin{array}{l}2 \text { Bölüm } \\
2 \text { Ölçme } \\
2 \text { Oran } \\
\text { 1Parça-bütün }\end{array}$ & $\begin{array}{l}1 \text { Bölüm } \\
1 \text { Ölçme } \\
1 \text { Oran }\end{array}$ & 1 Ölçme & $\begin{array}{l}3 \text { Bölüm } \\
4 \text { Ölçme } \\
3 \text { Oran } \\
\text { 1Parça-bütün }\end{array}$ \\
\hline Toplam & $\begin{array}{l}7 \text { Bölüm } \\
8 \text { Ölçme } \\
4 \text { Oran } \\
2 \text { İşlemci } \\
1 \text { Parça-Bütün }\end{array}$ & $\begin{array}{l}3 \text { Bölüm } \\
2 \text { Ölçme } \\
6 \text { Oran } \\
1 \text { Parça-Bütün }\end{array}$ & $\begin{array}{l}1 \text { Bölüm } \\
2 \text { Ölçme } \\
2 \text { Oran }\end{array}$ & $\begin{array}{l}11 \text { Bölüm } \\
12 \text { Ölçme } \\
12 \text { Oran } \\
2 \text { İşlemci } \\
2 \text { Parça-bütün }\end{array}$ \\
\hline
\end{tabular}

Kesrin anlamları açısından bakıldığında, son klinik görüşmede; yazılan problemlere en fazla kesrin ölçme anlamı verilebilmiştir. Katılımcıların tamamı kesrin bölüm, oran, ölçme ve işlemci anlamına dair problem yazabilirken, Berna ayrıca kesrin parça-bütün anlamına dair de problem yazabilmiştir. Yazılan problemlere en çok kesrin ölçme anlamı verilmiş, en az ise kesrin parça-bütün anlamı verilebilmiştir. PcPdc kesirli ifadeleri içeren denklemlere sadece kesrin ölçme anlamı verilebilirken, PnPdc kesirli ifadeleri içeren denklemlere kesrin işlemci ve kesrin bölüm, oran ve ölçme anlamları verilebilmiş, PcPdn kesirli ifadeleri içeren denklemlere ise kesrin 5 farklı anlamı da verilebilmiştir. Kalıcılık klinik görüşmede; yazılan problemlere en fazla kesrin ölçme ve oran anlamı verilebilmekle birlikte diğer anlamlarda kullanılmaya çalışılmıştır. En az kullanılan anlam parça bütün anlamı olmuştur. Katılımcılardan sadece Ayşegül kesrin 5 farklı anlamını da içeren problem yazabilirken, Berna sadece kesrin 3 farklı anlamına dair problem yazabilmiştir. Katılımcılar PcPdn kesirli ifadeleri içeren denklemlere kesrin 5 farklı anlamı da verilebilirken, PnPdc ifadelere kesrin işlemci dışındaki diğer 4 farklı anlamını verilebilmişlerdir. PcPdc ifadeleri içeren denklemlere ise kesrin bölüm, ölçme ve oran anlamı verilebilmişlerdir.

Her iki klinik görüşmede de kesrin bölüm, oran ve ölçme anlamlarının daha yoğun kullanıldığg görülmektedir. Kalıcılık klinik görüşmede son klinik görüşmeye kıyasla kesrin ölçme anlamında önemli düzeyde bir azalma olduğu, kesrin oran anlamında ise artış olduğu görülmektedir. Bu durumun son klinik görüşmelerin öğretim seanslarından 1 hafta sonra gerçekleştirilmesinden ve öğretim seanslarında çözdürülen problemlerde ölçme anlamının biraz daha fazla kullanılmasından kaynaklanabileceği düşünülmektedir. Yaklaşık 3 aylık bir geri çekilme sürecinin ardından ise yazılan problemlerde kesrin farklı anlamlarının kullanımının son klinik görüşmeye gore daha dengeli olduğu görülmektedir. 


\section{Sonuç, Tartışma ve Öneriler}

Cebirsel kesirli ifadeleri içeren denklemlere dair kavramsal bilginin değişim sürecinin incelendiği bu araştırmada elde edilen ilk sonuç; problemlerde en çok kullanılan anlamların kesrin bölüm anlamı ile oran ve ölçme anlamları olduğudur. Bu araştırmanın aksine Öksüz (2004) çalışmasında öğrencilerin kesrin gelişim sürecinde öncelikle parça-bütün anlayışına sahip olduklarını daha sonra paylaştırma yani bölüm olarak algıladıklarını, kesirler ve cebirsel kesirlerle ilgili farklı anlayışlara sahip olduklarını vurgulamıştır. Bu araştırmada ise cebirsel kesirli ifadelerde kesrin bölüm anlamı katılımcıların ilk aklına gelen ve en çok kullanılan anlam olmuştur. Ayrıca Öksüz (2004) çalışmasında bu araştırmanın sonuçlarını destektekleyen sonuçlara da ulaşmıştır. Öğrenciler kesrin anlamını geliştirdikten sonra sorunun başka boyutlarını kurabilmişlerdir. Bu araştırmada da öğrencilerin problem kurma sürecini benzer şekilde gerçekleştirdikleri görülmüştür. Öncelikle kesrin anlamını oluşturmaya çalışmış, ardından problemin diğer boyutlarını oluşturmuşlardır.

Kesrin işlemci ve parça bütün anlamları ise en az kullanılan anlamlar olmuştur. Bu durumun birkaç faktöre bağlı olabileceği düşünülmektedir. Etkili olan faktörlerden belkide en önemlisi uygulama esnasında katılımcılara başka bir müdahelede bulunmamakla birlikte sunulan konular ve oluşturulan problemlerin yorumlatılması olmuştur. Diğer bir faktör ise öğretim seanslarından sonra katılımcılara çözmeleri için sunulan ve kesrin farklı anlamlarını içeren problemlerdir. Parça-bütün anlamı bu problemlerde en az kullanılan anlam olmuştur. Ancak yazılan problemler genellikle doğrudur ya da eksik bırakılmıştır. Işık ve Kar'ın (2012) araştırması da bu araştırmayı destekler niteliktedir. Araştırmacılar 7. sınıf öğrencilerinin kesirlerde toplama işlemine dair sözel problem kurabilme durumlarını incelemişler ve öğrencilerin yaşayabilecekleri zorlukları araştırmışlardır. Kesrin parçabütün ilişkisini kuramama, buldukları zorlukların arasında yer almaktadır. Benzer durum bu araştırmada da mevcuttur. Katılımcılar verilen denklemlerde kesrin parça-bütün ilişkisini kurmada zorluk yaşamışlar ve bazı problemleri yarım bırakmışlardır. Kesrin işlemci anlamı açısından bakıldığında; uygulama esnasında katılımcılardan sözel problem yazmaları istendiği için kesrin bu anlamını kullanmaktan kaçınmış olmaları bu sonucun ortaya çıkmasında etkili olabilir. Bu araştırmanın aksine Öksüz'ün (2004) araştırmasında öğrenciler kesrin işlemci anlamını cebirsel kesirlerde kullanıp numerik kesirlerde kullanmamışlardır. Öksüz’e (2004) göre bunun nedeni öğrencilerin algoritmik işlemlerle cebirsel kesirler arasında hızlı bir ilişki kurma istekleri olarak belirtilmektedir.

$\mathrm{Bu}$ araştırmadan elde edilen diğer bir sonuç ise cebirsel kesirli ifadeleri içeren denklemlere yazılan sözel problemlerde kullanılan kesrin anlamlarının, kesrin türü ile ilişkili olduğudur. İşlemci anlamı sadece Pc Pdn cebirsel kesirli ifadeleri içeren denklemde kullanılırken, bölüm anlamı en çok Pc Pdn cebirsel kesirli ifadeleri içeren denklemlerde kullanılmıştır. Ölçme ve parça-bütün anlamı bütün kesir türlerinde kullanılmıştır. Oran anlamı ise daha çok Pc Pdc kesirli ifadeleri içeren denklemlerde kullanılabilmiştir. Bu konuda alanyazında yapılmış herhangi bir çalışma ile karşılaşılmamıştır. Bu sonucun cebirsel kesirli ifadelerin kavramsal kısmına yeni bir bakış açısı getirebileceği düşünülmektedir. Araştırmada oluşturulan problemlerde katılımcıların genellikle sözel ve günlük dili kullandıkları belirlenmiştir. Bu konuda Ünlü ve Sarpkaya Aktaş (2017) ilköğretim matematik öğretmeni adaylarının cebirsel ifade ve denklemlere ilişkin kurdukları problemleri incelemişlerdir. Sonuç olarak ögretmen adaylarının cebirsel ifade ve denklemlere yönelik genel olarak sözel ve çözülebilen problemler kurdukları, kurulan problemlerde genellikle günlük dili kullandıkları tespit edilmiştir. Bu araştırma üniversite düzeyinde yapılmış olmakla birlikte mevcut araştırmanın sonuçları ile benzer niteliktedir. $\mathrm{Bu}$ araştırmanın aksine Işık ve Kar (2012a) tek bilinmeyenli doğrusal ve ikinci dereceden denklemlere öğretmen adaylarının kurdukları sözel problemleri araştırmışlar ve matematiksel ögeleri sözel ifadeye yanlış çevirdiklerini belirtmişlerdir.

Kesirden cebirsel kesirlere geçiş, karmaşık bir süreçtir ve kavramlara ilişkin pek çok kavram hatası ve yanlış anlama bu geçişi zorlaştırır (Öksüz, 2004). Bu araştırmada da uygulama başlamadan önce 
katılımcılar cebirsel kesirli ifadeleri içeren denklemlere genellikle yanlış sözel problemler yazmışlar, problemleri eksik bırakmışlar ya da hiç problem yazmamışlardır. Notasyonu değiştirme, sözel problemde soru olmaması, eksik veri kullanma, matematiksel içerik ekleme, hatalarının kesrin anlamı ile ilgili olmadığı düşünülürken kesirli değişken ile kesirli olmayan değişkeni karıştırma, değişkenin anlamında kargaşa, pay-payda karıştırma, günlük hayatla ilişkilendirememe hatalarının kesrin anlamı ile ilgili olduğu görülmüştür. Ayrıca yapılan hatalar kesrin anlamına göre farklılıklar göstermektedir. Örneğin, pay ve payda karışımı kesrin ölçme anlamını içeren sözel problemlerde ölçmenin temel birimi ile ilgili iken oran sözel problemlerinde birimlerin birbirine oranı söz konusudur. Bu nedenle kesrin farklı anlamlarına göre yazılan problemlerde yapılan hatalar da farklılık göstermektedir. Alanyazında bu sonuç ile ilgili herhangi bir çalışmaya rastlanmamıştır. Bu noktada bu sonucun cebirsel kesirli ifadelerin kavramsal kısmına yeni bir boyut katabileceği vurgulanabilir. Öğretim seansları ile beraber yapılan hata sayısı azalmış, son klinik görüşme ve kalıcılık klinik görüşmede yapılan hata türleri denklemi değiştirme ve sözel problemde gerçeğe uygunluk olarak belirlenmiştir. denklemi değiştirme hatası öğretim seanslarının sonuna doğru azalmış, ancak tamamen önlenememiştir. Gerçeğe uygunluk ise daha sonra ortaya çıkan ve önlenememiş diğer bir hata türüdür.

$\mathrm{Bu}$ araştırmada belirlenen bazı hataların başka çalışmalarda da görüldüğü belirlenmiştir. Işık ve Kar (2012), 7. sınıf öğrencilerinin kesirlerde toplama işlemine dair kurdukları sözel problemlerde, toplanan ikinci kesri bütünün kalanı üzerinden ifade etme, parça-bütün ilişkisini kuramama, işlem sonucuna doğal sayı anlamı yükleme, birim kargaşası, toplanan kesir sayılarına doğal sayı anlamı yükleme, işlemi soru köküne yansıtamama ve tamsayılı kesirlerin tam kısımlarına anlam yükleyememe şeklinde yedi güçlük tespit edilmiştir. Alibali vd. (2014) ortaokul öğrencilerinin doğrusal ve bir bilinmeyenli denklemlerle ilgili denklem sorularını dönüştürmeleri sözel problemlerde öğrencilerin kavramsal anlamalarında çarpma işlemi ile sembolik sunumu arasındaki bağ 1 anlamada eksiklikleri olduğunu ve tutarlı bir hikâye içerisinde çoklu matematiksel işlemleri göstermede zorluk yaşadıklarını belirtmişlerdir. 


\section{Kaynakça}

Acar, N. (2010). Kesir Çubuklarının İlköğretim 6. Sınıf öğrencilerinin Kesirlerde Toplama ve Çıkarma Işslemlerindeki Başarılarına Etkisi. Yayınlanmış Yüksek Lisans Tezi. Selçuk Üniversitesi, Fen Bilimleri Enstitüsü, Konya.

Alacaci, C. (2012). Öğrencilerin kesirler konusundaki kavram yanılgıları. Bingölbali, E ve Özmantar, M., F. (Edt). İlkögrretimde Karşılaşılan Matematiksel Zorluklar ve Çözüm Önerileri. Ankara: Pegem Akademi

Alibali, Martha W., Mitchell J. Nathan, Matthew S. Wolfgram, R. Breckinridge Church, Steven A. Jacobs, Chelsea Johnson Martinez \& Eric J. Knuth (2014) How Teachers Link Ideas in Mathematics Instruction Using Speech and Gesture: A Corpus Analysis, Cognition and Instruction, 32:1, 65-100, DOI: $10.1080 / 07370008.2013 .858161$

Behr, M.J., Lesh, R., Post, T.R., and Silver, E.A. (1983). Rational number concepts. In R. Lesh, and M. Landau (Eds.), Acquisition of mathematics concepts and processes (92-127). New York: Academic Press.

Behr, M., Harel, G., Post, T., \& Lesh, R. (1992). Rational number, ratio, and proportion. In D. Grouws (Ed.), Handbook for research on mathematics teaching and learning (pp. 296-333). New York: Macmillan.

Birgin, O. ve Gürbüz, R.(2009). İlköğretim II. Kademe Öğrencilerinin Rasyonel Sayılar konusundaki İşlemsel ve Kavramsal Bilgi Düzeylerinin İncelenmesi. Eğitim Fakültesi Dergisi, XXII (2), 2009, $529-550$

Booth, L. R. (1986). Difficulties in algebra. Australian Mathematics Teacher, 42(3), 2-4.

Booth, L. R., \& Watson, J. (1990). Research for teaching: Learning and teaching algebra. Australian Mathematics Teacher, 46(3), 12-14.

Crooks, N. M. \& Alibali, M. W. (2014). Defining and measuring conceptual knowledge of mathematics. Developmental Review. doi: 10.1016/j.dr.2014.10.001

Güveli, E. (2015). "Prospective Elementary Mathematics Teachers' Problem Posing Skills About Absolute Value". Turkish Journal of Teacher Education (2015): 1-17.

Işık, C. (2011). İlköğretim matematik öğretmeni adaylarının kesirlerde çarpma ve bölmeye yönelik kurdukları problemlerin kavramsal analizi. Hacettepe Üniversitesi Eğitim Fakültesi Dergisi, 41, 231-243.

Işık, C. ve Kar, T. (2012). Matematik dersinde problem kurmaya yönelik öğretmen görüşleri üzerine nitel bir çalışma. Millî Ĕgitim. Sayı 194/ Bahar/ 2012 (s. 199-215)

Kılıç, Ç. (2013). Pre-service primary teachers' free problem-posing performances in the context of fractions: An example from Turkey. The Asia-Pacific Education Researcher, 22, 1-10.

Kieren, T. E. (1976) On the mathematical, cognitive and instructional foundations of rational numbers. In: Lesh, R. (ed) Number and measurement: papers from a research workshop. Columbus, Ohio: Eric/Smeac, p. 101-144.

Kieran, C. (1981). Concepts associated with the equality symbol. Educational Studies in Mathematics, 12, 318-326. http://dx.doi.org/10.1007/BF00311062

Kieren, T. E. (1988). Personal knowledge of rational numbers: Its intuitive and formal development. In J. Hiebertand M. Behr (Eds.), Number concepts and operations in the middle grades (162-181). Reston VA: The National Council of Teachers of Mathematics.

Kilpatrick, J., Swafford, J. O., \& Findell, B. (2001). Adding it up: Helping children learn mathematics. Washington, DC: National Academies Press. 
Lavy, I., \& Bershadsky, I. (2003). Problem posing via "what if not?'” strategy in solid geometry a case study. Journal of Mathematical Behavior, 22, 369-387.

MEB. (2013). Ortaokul matematik dersi ögretim programı. Retrieved March, 15, 2013 from http://ttkb.meb.gov.tr/www/guncellenen-ogretim-programlari-ve kurulkararlari/icerik/150.

Miles, M, B., \& Huberman, A. M. (1994). Qualitative data analysis: An expanded Sourcebook. (2nd ed). Thousand Oaks, CA: Sage.

National Council of Teachers of Mathematics. (2000). Principles and standards for school mathematics. Reston, VA: Author. Fractions: Children's strategies and errors: A report of the strategies and error in secondary mathematics Project NFER-Nelson, Windson (1986)

National Council of Teachers of Mathematics [NCTM]. (2011). Principles and standards for school mathematics. Reston, Va: National Council of Teachers of Mathematics.

Olkun, S., Uçar, Z. T. (2007) İlköğretimde Etkinlik Temelli Matematik Öğretimi (üçüncü baskı), Ankara: Maya Akademi.

Öksüz, C. (2004). Children understanding of algebric fraction as quotients. (Unpublished doctoral dissertation). University of Arizona, Arizona

Patton, M.Q. (1997). How to use qualitative methods in evaluation. Newbury park, CA: SAGE Publications

Pope, L. (1994), Teaching Algebra. Mathematics Education: A Handbookfor Teachers. elsington College of Education: New Zealand, 1, 88-99.

Sasman, M. Linchevski, L., Olivier, A. 1997. Reconceptualising school algebra. Internet: http://academic.sun.ac.za/mathed/MALATI/Rational.pdf

Saxe, G.,Gearhart, M., and Nasir, N. S. (2001). Enhancing students' understanding of mathematics: A study of three contrasting approaches to Professional support Journal of Mathematics Teacher Education, 4, 55-79.

Schoenfeld, A. ve Arcavi, A. (1988). On the meaning of variable. Mathematics Teacher. 81 (6), 420-427.

Sheffield, L. J., \& Cruikshank, D. E. (2005). Teaching and learning mathematics pre-kindergarten through middle school. Hoboken, N.J.: Wiley Jossey Bass Education

Silber, S., \& Cai, J. (2017). Pre-service teachers' free and structured mathematical problem posing, International Journal of Mathematical Education in Science and Technology, 48(2), 163-184

Silver, E. A. (1994). On mathematical problem posing. For the Learning of Mathematics. 14(1), 19-28.

Skemp, R., R. (1976). Relational Understanding and Instrumental Understanding. Department of Education, University of Warwick (http://static1.squarespace.com/static/ 53b6662ae4b00ce9a7c30e76/t/5548a95ae4b03cee0387aef9/1430825306203/Mona+Rosseland+12. 11.14+Vedlegg.pdf)

Skemp, R. R. (1978). Relational and instrumental understanding. Arithmetic Teacher, 26, 9-15.

Stacey, K., and MacGregor, M. (1997b). Ideas about symbolism that students bring to algebra. Mathematics Teacher, 90, 110-113.

Star, J. R. (2005). Reconceptualizing procedural knowledge. Journal for Research in Mathematics Education, 36, 404-411.

Star, J. R. (2007). Foregrounding procedural knowledge. Journal for Research in Mathematics Education, 38(2), 132-135.

Steffe, L. P., and Thompson, P. W. (2000). Teaching experiment methodology: Underlying principles and essentialelements. In R. Lesh\& A. E. Kelly (Eds.), Research design in mathematics and science education (pp. 267- 307). Hillsdale, NJ: Erlbaum. 
Stoyanova, E. \& Ellerton, N. F. (1996). A framework for research into students' problem posing in school mathematics. In P. Clarkson (Ed.), Technology in mathematics education (pp.518-525). Melbourne: Mathematics Education Research Group of Australasia.

Stoyanova, E. (2003). Extending students' understanding of mathematics via problem posing. The Australian Mathematics Teacher, 59(2), 32-40.

Şengül, S. \& Katranc1, Y. (2012). Problem solving and problem posing skills of prospective mathematics teachers about the 'sets' subject. Procedia - Social and Behavioral Sciences, 69, 1650 - 1655.

Şengül, S. \& Katranc1, Y. (2015). Free problem posing cases of prospective mathematics teachers: Difficulties and solutions. Procedia - Social and Behavioral Sciences, 174, 1983 - 1990.

Şengül, S ve Öz, C. (2008). İlköğretim 6. Sınıf Kesirler Ünitesinde Çoklu Zekâ KuramınaUygun Öğretimin Öğrenci Tutumuna Etkisi. İlkögretim Online, 7(3), 800-813, 2008. [Online]: http://ilkogretim-online.org.tr

Ticha, M., \& Hošpesová, A. (2009, Ocak). Problem posing and development of pedagogical content knowledge in pre-service teacher training. Paper presented at Congress of European Research in Mathematics Education (CERME 6), Lyon, France.

Toluk, Z. (2001). Eşit paylaşım ortamlarının kesir öğretiminde kullanımı. Kuram ve Uygulamada Eğitim Bilimleri. 1 (1)

Toluk-Uçar, Z. (2009). Developing pre-service teachers understanding of fractions through problem posing. Teaching and Teacher Education, 25(1), 166-175.

Ünlü, M. \& Ertekin, E. (2012). Why do pre-service teachers pose multiplication problems instead of division problems in fractions? Procedia - Social and Behavioral Sciences, 46, 490 - 494.

Ünlü, M. ve Sarpkaya Aktaş, G. (2017). Ortaokul matematik öğretmeni adaylarının cebirsel ifade ve denklemlere yönelik kurdukları problemlerin incelenmesi. Turkish Journal of Computer and Mathematics Education Vol.8 No.1 (2017), 161-187

Vacc, N. N. (1993). Implementing the' Professional standards for teaching mathematics': questioning in the mathematics classroom. Arithmetic Teacher, 41(2), 88-92.

Van De Walle, J., A., Karp, K., S. ve Bay-Williams, J., M. (2013). Ilkokul ve ortaokul matematiği, gelişimsel bir yaklaşımla (Durmuş, S. çev. Edt.). Nobel Akademik Yayıncılık, Ankara.

Van Harpen, X. Y., \& Sriraman, B. (2013). Creativity and mathematical problem posing: an analysis of high school students' mathematical problem posing in China and the USA. Educational Studies in Mathematics, 82, 201-221.

Yanık, H., B. (2015). Rasyonel sayılar. Zembat, İ., Ö., Özmantar, M., F., Bingölbali, E., Şandır, H. ve Delice, A. (Edt.). Tanımları ve Tarihsel Gelişimleriyle Matematiksel Kavramlar (sf. 95-110). Ankara: Pegem Akademi

Yanık, H. B. ve Serin, G. (2016). Two fifth grade teachers' use of real-world situations in science and mathematics lessons. The Clearing House: A Journal of Educational Strategies, Issues and Ideas, 89(1), 28-37.

Yıldırım, A. ve Şimşek, H. (2005) Sosyal Bilimlerde Nitel Aratırma Yöntemleri. (2. baskı). Ankara: Seçkin yayıncılık

Yıldız, A., \& Baltacı, S. (2015). İlköğretim matematik öğretmen adaylarının problem kurma etkinlikleri ile olasılığa yönelik bilgilerinin incelenmesi [Researching primary preservice mathematics teachers' knowledge of probability with problem posing activities]. Ahi Evran University Journal of Kirsehir Education Faculty (KEFAD), 16 (1), 201-213. 